\title{
KULT SIEDMIU ARCHANIOŁÓW W ŚREDNIOWIECZNEJ NUBII NA TLE KULTU SIEDMIU PLANETARNYCH BOGÓW W BASENIE MORZA ŚRÓDZIEMNEGO
}

\section{The cult of seven Archangels in medieval Nubia against the background of the cult of seven planetary gods in the Mediterranean}

\section{Abstract}

The works of Polish archaeologists in Sudan, ongoing since „The Nubian Campaign” (19611964), constantly enrich our knowledge about Christian Nubia. New research not only forces us to correct our knowledge on Nubia, but also to take a fresh look at Mediaeval Christianity. An interesting thread of Nubian angelology is the evidence of seven archangels' cult confirmed in inscriptions as well as in painting and architecture. In the case of Nubia we do not have extensive descriptions of the development of the archangels' worship, and our knowledge is based on the combination of individual data, which, when collected, may form a complete picture. The purpose of this paper is to gather these single tesserae and show that the worship of archangels was developing in Nubia and that there was a certain permanent set of the archangelic names.

Keywords: Nubia, Seven Archangels, Iconography, Cult, Planetary Gods

\section{Streszczenie}

Prace polskich archeologów w Sudanie, trwające od tzw. „Kampanii Nubijskiej” (1961-1964), stale wzbogacają wiedzę o chrześcijańskiej Nubii. Nowe badania nie tylko zmuszają do korygowania wiedzy na temat Nubii, ale także do świeżego spojrzenia na średniowieczne chrześcijaństwo. Ciekawym wątkiem nubijskiej angelologii są świadectwa kultu siedmiu archaniołów potwierdzone w inskrypcjach, a także w malarstwie i architekturze. W przypadku Nubii nie zachowały się obszerne opisy rozwoju kultu archaniołów i wiedza opiera się na łączeniu pojedynczych informacji, które po zebraniu tworzą pełny obraz. Celem

\footnotetext{
1 Magdalena Łaptaś jest historyczką sztuki i archeolożką pracującą w Uniwersytecie Kardynała Stefana Wyszyńskiego w Warszawie. Jej głównym obszarem badawczym jest sztuka basenu Morza Śródziemnego, ze szczególnym uwzględnieniem ikonografii malarstwa pozyskiwanego podczas polskich wykopalisk. Od 2001 r. bierze udział w wykopaliskach w Banganarti (Sudan).E-mail: magda.laptas@gmail.com.
} 
niniejszego artykułu jest zebranie tych informacji i pokazanie, iż kult archaniołów rozwijał się w Nubii i istniał pewien stały skład imion tych archaniołów.

Słowa kluczowe: Nubia, siedmiu archaniołów, ikonografia, kult, planetarne bóstwa

$\mathrm{K}$ ult siedmiu archaniołów w Nubii trafił na dobrze przygotowany grunt, jakim był kult siedmiu opiekuńczych bóstw na Bliskim Wschodzie i w basenie Morza Śródziemnego. Poświadczony był on już w Mezopotamii, gdzie wyróżniono siedem ,planet” widocznych „gołym okiem”. Faktycznie tylko pięć z nich to planety, a dwie pozostałe to Słońce (które jest gwiazdą) oraz Księżyc (będący satelitą Ziemi). Siedem „planet” połączono z bogami panteonu babilońskiego ${ }^{2}$. Na podstawie obserwacji faz księżyca sumeryjscy, a potem babilońscy astronomowie wyróżnili siedmiodniowy tydzień.

Oprócz kultu siedmiu planet, w Mezopotamii rozwijał się kult bóstw opiekuńczych Sebittu, łączonych z gromadą gwiazd w konstelacji Byka, zwanych Plejadami. Mimo iż gromada Plejad obejmuje ok. 500 gwiazd, najlepiej widać ,gołym okiem” siedem z nich. W neosumeryjskim okresie Siódemkę postrzegano jako wojowników, wspierających kosmicznego władcę 3 . O rozprzestrzenieniu kultu Sebittu świadczą dedykowane im świątynie w takich miastach jak: Aszur, Niniwa czy Babilon ${ }^{4}$.

Na pieczęciach cylindrycznych w okresach neo-asyryjskim i neo-babilońskim pojawiało się siedem kropek w partii nieba, łączonych z symboliką Sebittu5. W Mezopotamii wierzono, iż układ planet w momencie narodzenia dziecka przesądzał o jego dalszych losach. A zatem, planetarni bogowie mieli decydujący wpływ na losy ludzi. Od ich opieki zależało całe dalsze ludzkie życie.

Podobne przekonanie panowało w Egipcie, w którym rolę opiekuńczej bogini pełniła Hathor. W siedmiu postaciach Hathor zjawiała się przy łożach noworodków, by przepowiadać im przyszłość ${ }^{6}$. Od jej nastawienia zależało to, czy dalsze życie dzieci przebiegało pomyślnie. Przeciwieństwem siedmiopostaciowej Hathor była groźna bogini Sechmet. Występowała ona także w siedmiu postaciach i mogła sprowadzać na ludzi różne choroby ${ }^{7}$. Modlono się zatem do siedmiopostaciowej Hathor z prośbą o ochronę przed szkodliwym działaniem Sachmet i chorobami ${ }^{8}$. Siedem opiekuńczych Hathor przedstawiano jako rząd młodych kobiet z krowimi rogami, pomiędzy którymi umieszczano dyski solarne. Przykładem może być relief ze świątyni tej bogini w Denderze ${ }^{9}$. Interesujące, z punktu widzenia dalszych

\footnotetext{
2 G. Dix, The Seven Archangels and the Seven Spirits: A Study in the Origin, Development and Messianic Associations of the Two Themes. "Journal of Theological Studies", 28/1927, s. 234-235.

3 F.A.M. Wiggermann, Siebengötter, w: Reallexikon der Assyriologie und vorderasiatischen Archäologie, z. 12 (5/6), red. S. Ecklin, S. Pfaffinger, Berlin-New York 2010, s. 459.

4 E. Douglas van Buren, The Seven Dots in Mesopotamian Art and their Meaning, "Archiv für Orientforschung", 13/1939/1941, s. 278 .

5 Por. D. Collon, First Impressions. Cylinder Seals in the Ancient near East, wyd. 2, London 2005, nr 345, s. 77-8; nr 811, s. 175-175.

6 W. Helck, Hathoren, Sieben, w: Lexikon der Ägyptologie, t. 2, red. W. Helck, Wiesbaden 1977, kol.1033.

7 Ancient Egyptian Magical Texts, red. i thum. Borghouts, Leiden 1978, "Nisaba”, t. 9: Brill, 2, 37-38.

8 Por. W.A. Dawson, “Seven” in Egyptian Texts, “Aegyptus”, 8/1927, nr 1/2, s. 98. Autor tego artykułu omawia m.in. przykłady zwielokrotniania różnych bogów do siedmiu postaci w egipskich tekstach. Ancient Christian Magic. Coptic Texts of Ritual Power, red. M. Meyer, R. Smith, Princeton 1999, s. 150.

9 Por. É. Chassinat, F. Daumas, Le temple de Dendera VI, Le Caire 1965, tabl. DXLVII, DXLVIII.
} 
rozważań na temat chrześcijańskiej Nubii, jest to, iż w kompleksie tej świątyni (z okresu późnoptolemejskiego i rzymskiego) znajdował się budynek, w którym chorych poddawano leczeniu poprzez inkubację ${ }^{10}$.

Astronomowie starożytnej Grecji przejęli wiedzę o siedmiu planetach z Mezopotamii i nadali im nazwy bogów swojego panteonu. Z kolei Rzymianie przekształcili nazwy planet, odpowiednio nadając im imiona: Sol, Luny, Merkurego, Wenus, Marsa, Jupitera i Saturna. Te nazwy funkcjonują do dziś, gdyż dzięki diagramom Pliniusza Starszego wiedza starożytna przeniknęła do astronomii średniowiecznej (Fig. 1). Pisał on: „Pomiędzy nią [ziemią - przyp. autorki] a niebem wisi w tym samym powietrznym żywiole siedem gwiazd oddzielonych od siebie określonymi odległościami, które ze względu na właściwość ich ruchu nazywamy błądzącymi, chociaż żadne «gwiazdy» nie błądzą mniej od nich" (Hist. Nat. II: 4, 12) ${ }^{11}$.

Po podboju Babilonii, przez Aleksandra Wielkiego, wiedza o siedmiodniowym tygodniu rozprzestrzeniła się w basenie morza Śródziemnego. Ewoluowała w Aleksandrii, a następnie dotarła do Rzymu. O tym, iż Rzymianie przejęli system podziału tygodnia na siedem dni pisał Kasjusz Dion (162/163): „Egipcjanie wprowadzili zwyczaj odnoszenia dni do siedmiu gwiazd zwanych planetami. Występuje on teraz u wszystkich ludzi, choć przyjęto go stosunkowo niedawno. W każdym razie starożytni Grecy wcale go nie znali, o ile mi wiadomo. Ale zadomowił się teraz na dobre i u innych ludzi, i u Rzymian, u których do pewnego stopnia jest częścią ojczystej tradycji” (Historia Rzymska 37, 18: 1-2)12.

Konstantyn Wielki w 321 r. wprowadził do rzymskiego kalendarza siedmiodniowy tydzieńn ${ }^{13}$. Dni tygodnia zostały nazwane imionami bogów rzymskich, czyli: dies Solis, dies Lunis, dies Martis, dies Mercurii, dies Jovis, dies Veneris, dies Saturnae.

Zarówno w malarstwie, jak i mozaikach rzymskich często przedstawiano planetarnych bogów. W 1760 r. Karl Weber odsłonił w Pompejach (Ins. Occ. VI) malowidła ukazujące serię postaci w medalionach, datowane na poł. I w.n.e. (Narodowe Muzeum Archeologiczne w Neapolu, Nr 9519). W siedmiu medalionach ukazano bogów, będących opiekunami poszczególnych planet (Fig. 2) ${ }^{14}$. Kolejny przykład to mozaika podłogowa odkryta w domu zw. „Casa de Planetarium” w Italice, datowana na poł. II w.n.e. Pośrodku mozaiki przedstawiono popiersie bogini Wenus, ujęte w heksagonalnym polu, które obiega sześć pól z popiersiami pozostałych sześciu planetarnych bogów ${ }^{15}$. Na mozaice znalezionej niedaleko Zaghouan w Tunezji (Narodowe Muzeum w Bardo) postacie bogów również wpisano w heksagonalne pola, zaś pośrodku umieszczono wizerunek Saturna, a na zewnątrz jeszcze dwanaście znaków zodiaku' ${ }^{16}$.

\footnotetext{
10 J.F. Nunn, Ancient Egyptian Medicine, Norman OK. 2002, s. 111.

11 Gajusz Pliniusz Secundus, Historia Naturalna 1. Kosmologia i Geografia. Księgi II-VI, wstęp, kom. i tłum. I. Mikołajczyk et al., Toruń 2017, s. 59.

12 Kasjusz Dion Kokcejan, Historia Rzymska 1, tłum. W. Madyda, Wrocław-Warszawa-Kraków 1967, s. 127.

13 M. Wallraff, Christus verus Sol: Sonnenverehrung und Christentum in der Spätantike, Münster 2001, s. 96-102.

14 Ch.L. Long, The Pompeii Calendar Medallions. “American Journal of Archaeology”, 96/1992, nr 3, s. $480-484$.

15 K.M.D. Dunbabin, Mosaics of the Greek and Roman World, Cambridge-New York 1999, s. 150.

16 M. Yacoub, Splendeurs des mosaïques de Tunisie, Tunis 1995, s. 126-127, Fig. 54. Typ kompozycji ukazującej sześć heksagonalnych pól, obiegających centralnie umieszczone siódme pole, rozpowszechnił się w basenie Morza Śródziemnego. Świadczy o tym mozaika odkryta w sezonie 2019 na Kom el-Dikka w Aleksandrii przez polską misję archeologiczną pod kierunkiem Grzegorza Majcherka. W dzielnicy domów rzymskich z I-III wieku n.e. archeolodzy odsłonili zachowaną w całości wielobarwną mozaikę przedstawiającą rozety i kwiaty lotosu ujęte w heksagonalne pola, otoczone motywem plecionki (inf. Renata Kucharczyk).
} 


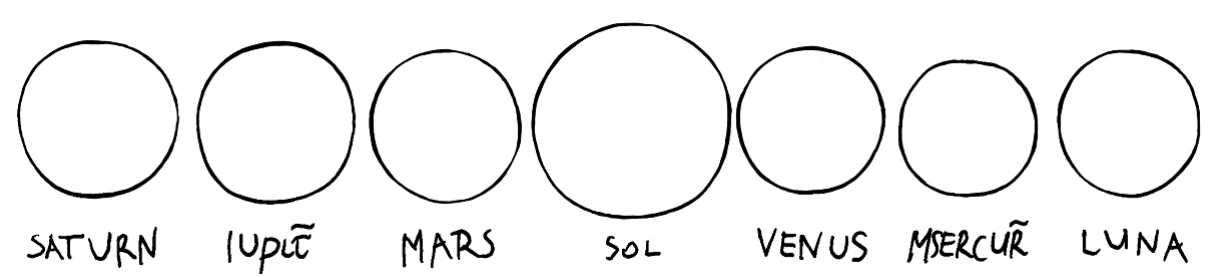

Fig. 1.
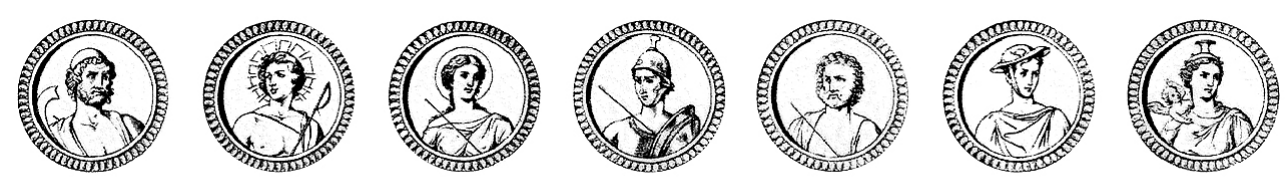

Fig. 2.

Przykładem podporządkowania budowli symbolice nawiązującej do ładu i harmonii kosmosu był rzymski Panteon, którego plan i każdy element odwzorowywał boską doskonałość wszechświata. Siedem apsyd we wnętrzu poświęcono siedmiu „gwiezdnym bóstwom”17. Panteon wpisuje się w długą tradycję, według której świątynia była domem Boga. Ta sama idea została przejęta i zastosowana w budowlach chrześcijańskich. Kościoły chrześcijańskie są obrazem świata, odzwierciedlają jego strukturalny charakter i geniusz Stwórcy ${ }^{18}$. W bizantyńskich kościołach sferą zarezerwowaną dla Boga były górne partie sklepień będące wycinkiem kuli: kopuły i konchy absyd ${ }^{19}$. Według zasady hierarchii zstępującej poszczególnym elementom wnętrz kościelnych, a także ich liczbie przypisywano właściwości symboliczne.

Zasada ta dotyczyła także chrześcijańskiej architektury w Nubii. Wykopaliska prowadzone na początku XXI w. w Banganarti doprowadziły do odkrycia Rafaelionu ${ }^{20}$. Jest on budowlą centralną, z naosem zwieńczonym pierwotnie kopułą, wspartą na czterech masywnych filarach. Część centralną obiega szereg niewielkich pomieszczeń, z których siedem, po stronie wschodniej, zakończonych jest apsydami. Tego typu rozwiązanie wschodniej partii kościoła jest niespotykane poza tą budowlą w architekturze nubijskiej. Należy zatem zadać sobie pytanie, jaki był cel takiego zaplanowania wschodniej partii budowli. Czy umieszczenie siedmiu apsyd po wschodniej stronie kościoła miało znaczenie symboliczne? Pewnej wskazówki dostarczył program ikonograficzny malowideł pokrywających tę część kościoła. W każdej z apsyd i na ścianach kaplic namalowano podobną kompozycję ukazującą władcę nubijskiego pod opieką archanioła oraz dwunastu apostołów. Równocześnie duża liczba graffiti pielgrzymów, pokrywających ściany budowli, świadczy, iż miejsce to było ośrodkiem

\footnotetext{
17 H. Stierlin, Imperium Romanum. Od Etrusków do upadku Cesarstwa Rzymskiego, tłum. A. Stawniak, J. Kołodziejczyk, Warszawa 1997, s. 158.

18 J. Hani, Świat symboliki chrześcijańskiej, tłum. A.Q. Lavique, Kraków 1998, s. 27.

19 K. Lechmann, The Dome of Heaven, "The Art Bulletin”, 27/1945, nr 1, s. 19.

20 Stanowisko to położone jest pomiędzy III i IV kataraktą na Nilu, w odległości ok. $11 \mathrm{~km}$ od Starej Dongoli. M. Łaptaś, Banganarti. The Wall Paintings, "Polish Archaeology in the Mediterranean. Reports 2003", 15/2004, s. 244.
} 
kultu archanioła Rafała. Archanioł ten, obdarzony imieniem teoforycznym (z hebr. rafa'el) $)^{21}$ oznaczającym „uzdrowienie Boże”, był opiekunem chorych i pogromcą demonów ${ }^{22}$. Taka funkcja została mu przypisana dzięki opiece nad młodym Tobiaszem, w drodze z Niniwy do Medii. Rafał pouczył młodego Tobiasza, jak zdobyć lekarstwa na uzdrowienie chorych oczu ojca i na wypędzenie demona. Nakazał Tobiaszowi zabezpieczyć wnętrzności ryby, którą złapał podczas kąpieli w Tygrysie i namówił młodego Tobiasza do małżeństwa z Sarą, córką Raguela (Tb 6,19). Sara była opętana przez demona Asmodeusza, który w trakcie nocy poślubnych zabił jej siedmiu mężów. Dzięki spaleniu wnętrzności ryby udało się wypędzić go z ciała dziewczyny. Gdy demon zaczął uciekać, Rafał podążył za nim aż do Górnego Egiptu, gdzie związał go i unicestwił. Po powrocie do rodzinnego domu w Niniwie Rafał poinstruował młodego Tobiasza, jak uleczyć chore oczy ojca. Dopiero gdy ojciec i syn chcieli mu zapłacić za pomoc, ujawnił swoją prawdziwą tożsamość mówiąc: „Ja jestem Rafał, jeden z siedmiu aniołów, którzy stoją w pogotowiu i wchodzą przed majestat Pański” (Tb 12,15). Biorąc pod uwagę, że Księga Tobiasza opisuje wydarzenia dotyczące niewoli asyryjskiej23, jest wielce prawdopodobne, że wiara w siedem niebiańskich istot została wprowadzona przez Żydów, którzy mieli kontakt z religią i astronomią Mezopotamii.

Nie tylko jednak w Księdze Tobiasza mowa jest o siedmiu aniołach. Także w Apokalipsie św. Jana pojawia się kilkakrotnie wzmianka o siedmiu duchach, które ,tworzą tron Boga” lub są w jego pobliżu (Ap 1,4) ${ }^{24}$. Podobieństwo siedmiu aniołów „,wchodzących przed Majestat Pański” do siedmiu Duchów, które są tronem Jahwe, lub też płoną jako lampy przed Jego tronem, zwraca uwagę na typologiczną zależność tej heptady. Duchy Boga są antytypami siedmiu aniołów, o których wspomina Rafał i do których sam się zalicza ${ }^{25}$.

Apokalipsa św. Jana zawiera dodatkowo wizję siedmiu aniołów dzierżących siedem trąb (Ap 8,6). Dźwięk poszczególnych trąb zapowiada kolejny kataklizm na niebie lub ziemi. Trąba siódmego anioła zapowiada „misterium Boga”(Ap 8,7 - 10,8), a więc Paruzję i Sąd Ostateczny.

Z opisów zawartych w Apokalipsie wynika, że aniołowie dmący w trąby mają potężną moc. Zarządzają oni żywiołami oraz decydują o losach: ludzi, zwierząt, wszystkiego, co związane z ziemią, ale także słońca, księżyca, gwiazd. W tym miejscu uwidacznia się podobieństwo pomiędzy aniołami a bogami planetarnymi, których czczono w Mezopotamii, Egipcie, Grecji i Rzymie. Orygenes (ok. 185-254), pisząc o aniołach, nawiązywał „do kultu gwiazd wśród Chaldejczyków”26. Jean Daniélou zauważył, że „ta myśl Orygenesa może być odebrana jako usprawiedliwienie oddawania czci gwiazdom"27. Kolejnym podobieństwem, jakie można zauważyć pomiędzy planetarnymi bogami a aniołami, jest łączenie ich z dniami tygodnia. Bóg stworzył świat w sześć dni, a siódmego dnia odpoczął (Rdz 1,3-31). Augustyn, identyfikował dni stworzenia z aniołami, pisząc: „A zatem jeśli aniołowie znajdują

21 D.I. Pallas, Himmelsmächte, Erzengel und Engel, w: Reallexikon zur byzantinischen Kunst III, red. K. Wessel, M. Restle, Stuttgart 1978, s. 48, 50.

22 G. Davidson, Stownik aniołów, w tym aniołów upadlych, tłum. J. Ruszkowski, Poznań 1967, s. 244.

23 W. Tyloch, Dzieje Ksiag Starego Testamentu. Szkice z krytyki biblijnej, Warszawa 1985, s. 372-373.

24 Por także: Ap 4,5; 5,6.

25 S. Kobielus, Concordia Novi et Veteris Testamenti. Zapowiedzi dzieła odkupienia i jego spetnienie w teologii i sztuce średniowiecza, Poznań 2013, s. 16.

26 J. Daniélou, Aniołowie i ich misja, tłum. K. Kubaszczyk, Warszawa-Ząbki 2006, s. 38.

27 Ibidem, s. 39 
się pomiędzy dziełami Bożymi owych dni - to są oni owym światłem, co otrzymało nazwę dnia" (Civ. Dei, 11: 9, 20) ${ }^{28}$.

Ta idea została ukazana w manuskrypcie zwanym Cotton Genesis, datowanym na VI w.n.e. Manuskrypt (silnie zniszczony przez ogień) zawierał miniatury ilustrujące stworzenie świata ${ }^{29}$. Poszczególne dni stworzenia ukazane były pod postacią aniołów ${ }^{30}$. Cotton Genesis przypisywany jest aleksandryjskiemu środowisku, w którym idea astrologicznego siedmiodniowego tygodnia ewoluowała w okresie hellenistycznym ${ }^{31}$. Innym zachowanym przykładem ukazania dni stworzenia pod postacią aniołów jest trzynastowieczna mozaika w kopule narteksu w kościele San Marco w Wenecji ${ }^{32}$. Widać zatem, iż idea łączenia aniołów z astronomią i dniami tygodnia rozwijała się w obszarze Morza Śródziemnego w późnym antyku i średniowieczu. Jak wcześniej wspomniano, już od czasów starożytnych wierzono, iż układ planet w chwili narodzenia dziecka decyduje o jego dalszych losach. Aniołowie z kolei pełnią funkcję opiekunów ludzi. Towarzyszą im od chwili poczęcia aż po śmierć. W wędrówce ich dusz w zaświaty prowadzą je przed Oblicze Boga. Każdy człowiek ma swojego anioła stróża: „Uważajcie, abyście nie pogardzali żadnym z tych maluczkich. Powiadam wam bowiem, że ich aniołowie zawsze widzą twarz mego Ojca w niebie” (Mt 18,9).

Mając możliwość dostępu do tronu i Oblicza Boga, zanoszą do niego prośby i modlitwy

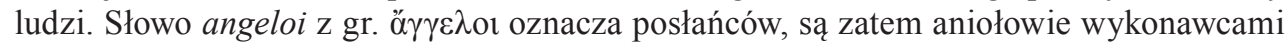
woli Boga. Wypełniając swą misję, unoszą się w przestworzach pomiędzy niebem i ziemią. To też upodabnia ich do bogów planetarnych. W swobodnym ruchu pomaga aniołom ich duchowa natura oraz skrzydła, o których nie ma co prawda wzmianki w Piśmie Świętym, jednak stały się one atrybutem archaniołów od końca IV w. i początku V w., co znalazło także potwierdzenie w pismach ojców Kościoła ${ }^{33}$. Skrzydła służą aniołom do przenoszenia się w przestworzach, mają także na celu ochronę wiernych, którymi aniołowie się opiekują.

W sztuce nubijskiej zachowało się wiele przykładów scen, w których postacie „protegowane" znajdują się pod skrzydłami archanioła lub też na jego skrzydle ${ }^{34}$. Wśród archaniołów ważne znaczenie w Nubii odgrywa dwóch z trzech wymienionych imiennie w Piśmie Świętym: Michał i Rafał ${ }^{35}$. Rola Gabriela w malarstwie nubijskim wydaje się mniej wyeksponowana, chociaż jako towarzysz archanioła Michała oraz zwiastun dobrych nowin zajmuje on także ważkie miejsce w hierarchii archaniołów. Granica pomiędzy przedstawieniami

\footnotetext{
28 Św. Augustyn, Państwo Boże, tłum. T. Kubicki, wstęp J. Salij, t. 2, Kęty 2015, s. 413.

29 K. Weitzmann, Late antique and early Christian book illumination, New York 1977, s. 28.

30 Idem, H.L. Kessler, The Cotton Genesis: British Library, Codex Cotton Otho B VI, Princeton 1986, s. 40, 48.

31 E. Zerubavel, The Seven Day Circle: The History and Meaning of the Week, New York-London 1989, s. 19.

32 O. Demus, The Mosaic Decoration of San Marco, Venice-Chicago 1988, s. 62; M. Büchsel, Die Schöpfungsmosaiken von San Marco. Die Ikonographie der Erschaffung des Menschen in der frühchristliche Kunst, ,Städel-Jahrbuch", 13/1992, s. 29.

33 G. Peers, Subtle Bodies. Representing Angels in Byzantium, Berkeley-Los Angeles-London, 2001, s. 23; E. Jastrzębowska, New Testament Angels in Early Christian Art: Origin and Sources, "Światowit", 8(49)/2011, fasc. A, s. 153 .

34 M. Łaptaś, Archangels as Protectors and Guardians in Nubian Art, w: Between the Cataracts. Proceedings of the $11^{\text {th }}$ Conference of Nubian Studies, Warsaw 27 August-2 September 2006, t. 2.2, red. W. Godlewski, A. Lajtar, Warszawa 2010, s. 676-680.

35 Eadem. The Archangel Raphael as protector, demon, tamer, guide and healer. Some aspects of the Archangel's activities in Nubian painting, w: Aegyptus et Nubia Christiana. The Włodzimierz Godlewski Jubilee Volume on the Occasion of his 70th Birthday, red. A. Lajtar, A. Obłuski, I. Zych, Warszawa 2006, s. 444.
} 
archaniołów i aniołów jest niekiedy płynna. Archaniołowie są wyżsi rangą niż aniołowie, a w sztuce nubijskiej jest to szczególnie podkreślane poprzez regalia, atrybuty i strój. Wydaje się, iż doskonałym przykładem takiego podziału rangi archaniołów i aniołów jest scena Bożego Narodzenia z Katedry w Faras, datowana na przełom X i XI w., w której każdy z trzech archaniołów wyróżniony jest poprzez indywidualny strój: Gabriel, jako zwiastun dobrej nowiny i posłaniec, odziany jest w białe szaty, Michał w loros, zaś Rafał w chlamidę ${ }^{36}$. Każdy z archaniołów dzierży w dłoniach sceptrum (zaś Michał i Rafał dodatkowo kadzielnice) (Fig. 3). Wokół szyi każdego z archaniołów widoczny jest maniakion, a głowę wieńczy korona. Siedmiu aniołów, ukazanych w locie, odzianych jest w białe szaty, zaś ich głowy wieńczą diademy, a nie korony. Wyraźnie zatem widać, iż w malarstwie nubijskim starano się zróżnicować rangę archaniołów i aniołów.

Imiona siedmiu aniołów nie są podane w Piśmie Świętym, jednak pojawiają się w literaturze apokryficznej. W Etiopskiej Księdze Henocha ${ }^{37}$ są to: Uriel (anioł gromu i drżenia), Rafał (anioł duchów ludzkich), Raguel (anioł zemsty nad światem świateł), Michał (który jest nad narodem [izraelskim]), Sarakael (któremu podlegają duchy ludzi nakłaniających do grzechu), Gabriel (któremu podlegają raj, węże i Cherubini), Remiel (którego Bóg ustanowił nad tymi, którzy powstają [z martwych]) (1 Hen 20,1-8) $)^{38}$.

Z kolei, w Hebrajskiej Księdze Henocha, Metatron wymienia siedmiu: „wspaniałych, pięknych, niezwykłych i chwalebnych" aniołów, którzy są wyznaczeni nad siedmioma niebami ${ }^{39}$. Są to: Michał, Gabriel, Szatkiel, Szataqiel, Baradiel, Baraqiel i Sidriel (Hen 3). Związek siedmiu archaniołów z kosmicznym obrazem świata jest oczywisty, bowiem sprawują oni opiekę nad siedmioma niebami, zgodnie z zasadą hierarchii zstępującej, od najwyższego nieba, którym zarządza Michał.

Tradycja nubijska wydaje się bliższa etiopskiej wersji Księgi Henocha. Zachowało się wiele list imion siedmiu archaniołów z terenów $\mathrm{Nubii}^{40}$. Na ścianie domu C1 w Kulubnarti amerykańska misja odkryła jedną z nich w ramach tzw. „Kampanii Nubiskiej” UNESCO, prowadzonej w latach 60. XX w. ${ }^{41}$ Imiona trzech pierwszych archaniołów: Michała, Gabriela i Rafała zachowane były w całości. W dalszej kolejności wymieniony był OYPOYPI ${ }^{42}$. Był to prawdopodobnie nubijski odpowiednik archanioła Uriela, przy czym imię to zostało tak zmodyfikowane, że zawierało w sobie słowo OYPOY - oznaczające po staronubijsku król. Pozostałe imiona zostały zidentyfikowane przez Adama Łajtara jako: Iael, Anael i Zedekiel ${ }^{43}$.

W odczytaniu imion wszystkich siedmiu archaniołów pozwoliły trzy listy odkryte w Starej Dongoli w trakcie polskich wykopalisk w zachodnio-północnym Aneksie Klasztoru

\footnotetext{
36 Por. eadem, Representation of the Angelic Hierarchy in a Nativity Scene from Faras Cathedral, "Gdańsk Archaeological Museum Reports", 2/2003, s. 137-143.

37 Najstarsze fragmenty tego dzieła datowane są na okres IV-II w. p.n.e., zaś najpóźniejsze na II w. n.e. Apokryfy Starego Testamentu, oprac. i wstępy R. Rubinkiewicz, Warszawa 2000, s. 142.

38 I Ksiega Henocha (Etiopska), tłum. M.I. Prokopowicz, w: Apokryfy Starego Testamentu, oprac., wstępy, R. Rubinkiewicz, Warszawa 2000, s. 150.

39 III Księga Henocha (Hebrajska), tłum, wstęp. i kom. M.I. Prokopowicz, https://www.academia.edu/12891881/ KSI\%C4\%98GA_HENOCHA_HEBRAJSKA (dostęp 21.08.2019), s. 31.

40 A. Łajtar, Varia Nubica XII-XIX, "Journal of Juristic Papyrology”, 39/2009, s. 31-67.

41 W. Adams, Kulubnarti I. The Architectural Remains, Lexington-Kentucky 1994, s. 303, nr 11.

42 A. Łajtar, op. cit., s. 64.

43 Ibidem, s. 65.
} 


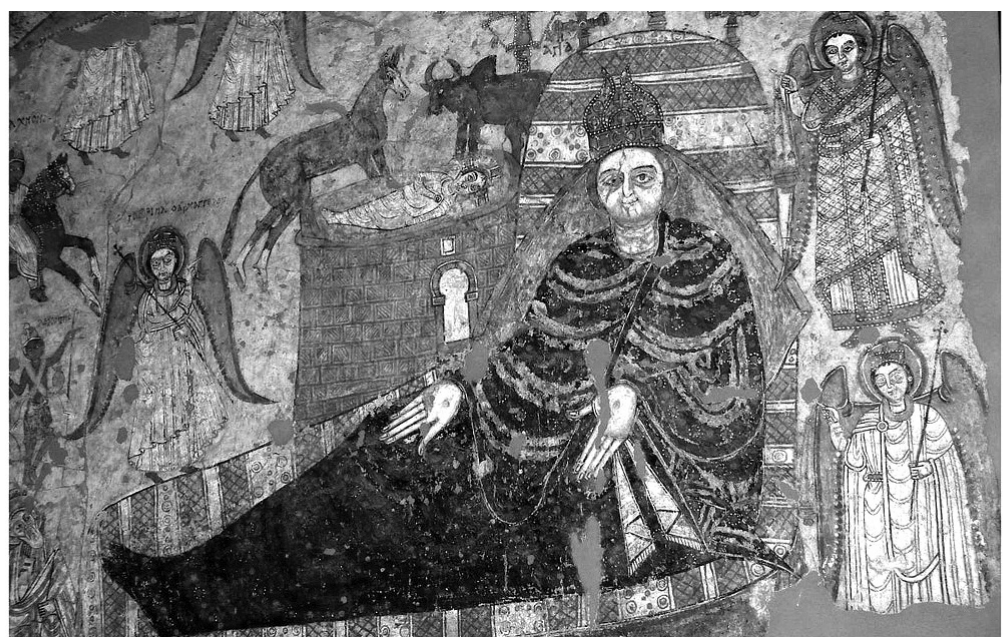

Fig. 3.

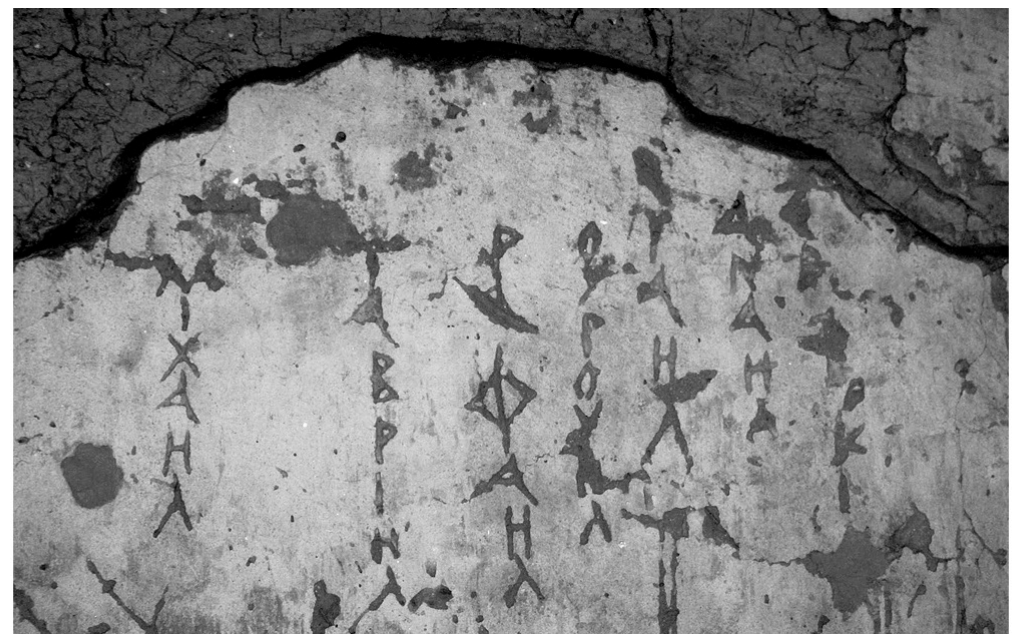

Fig. 4.

na Komie H. Pierwsza z nich, została zapisana na zachodniej ścianie Pomieszczenia 6. Na początku tej listy wymieniono Jezusa Chrystusa. Druga lista zachowała się niemal kompletnie na południowej ścianie Pomieszczenia 14, tego samego Aneksu (Fig. 4). Wreszcie kolejna lista wchodziła w skład magicznej inskrypcji, napisanej po grecku na północnej ścianie krypty grobowej (ok. 1100 n.e.), która znajdowała się pod Pomieszczeniem nr 544. Dwie dalsze listy zostały znalezione w Qasr Ibrim. Jedną z nich zapisano na ilustrowanej karcie papieru $^{45}$, zaś drugą na północnej ścianie grobu nr 366 (T 12), w okolicy wieży Katedry

\footnotetext{
44 Ibidem.

45 Ibidem, s. 66.
} 


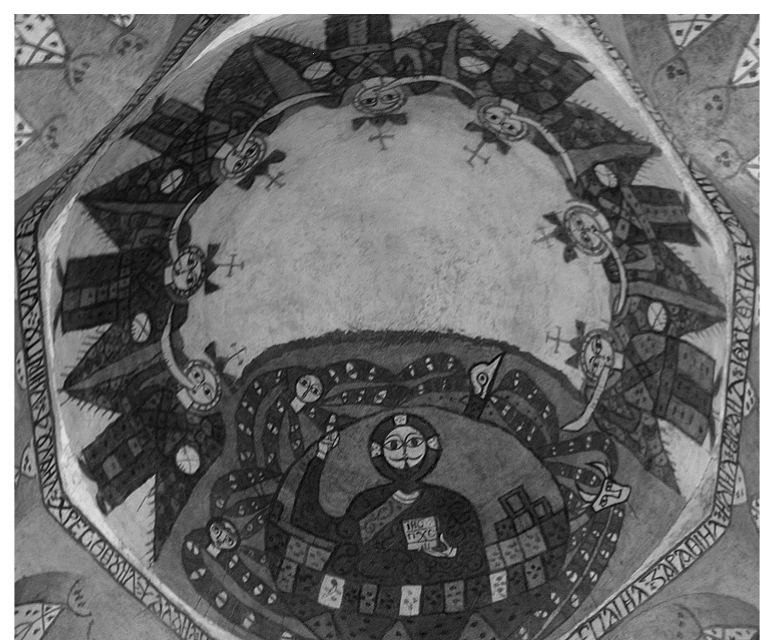

Fig. 5.

w Quasr Ibrim ${ }^{46}$. Ta ostatnia włączona jest w modlitwę do: Chrystusa, Matki Boskiej (?) i apostołów, zawierającą prośbę o ochronę (zmarłego) ${ }^{47}$. Ostatni przykład to inskrypcja $\mathrm{z}$ architrawu grobu w Qustul, przechowywana w Oriental Institute Museum Uniwersytetu w Chicago ${ }^{48}$. Imiona sześciu archaniołów wyryte były symetrycznie względem centralnie umieszczonego monogramu Chrystusa. Kontekst, w którym znajdowała się większość inskrypcji umieszczonych na ścianach domu, aneksu klasztornego i grobów, wskazuje, iż miały one znaczenie apotropaiczne ${ }^{49}$. Chroniły wiernych zarówno w trakcie ich życia, jak i po śmierci. Opublikowane przez Adama Łajtara przykłady świadczą o tym, iż w Nubii obowiązywał stały zestaw archaniołów. Składał się on z trzech archaniołów wymienianych w Piśmie Świętym, Uriela - Uruela (w wersji nubijskiej) oraz bardziej enigmatycznych: Iaela, Anaela i Zedekiela. Iael (hebr. Ya’el) oznacza siłę Boga; w magicznych, żydowskich zaklęciach jego imię stosowane było przeciwko zapomnieniu ${ }^{50}$. Anael (hebr. Ana'el) - łaska Boga $^{51}$, często łączony był z planetą Wenus i wymieniany w koptyjskich magicznych tekstach jako archanioł posłuszeństwa ${ }^{52}$. Imię siódmego archanioła (hebr. Zadeki'el) oznaczało boską sprawiedliwość. Był on aniołem dobroczynności, miłosierdzia i pamięci ${ }^{53}$.

Interesujące jest zestawienie siedmiu archaniołów z Chrystusem. Imiona siedmiu aniołów wyrażały Chrystusa, na co zwrócił uwagę Joseph Barbel, dedykując podrozdział książki

\footnotetext{
46 A. Łajtar, J. van der Vliet, Qasr Ibrim. Greek and Coptic Inscriptions, Warszawa 2010, “Journal of Juristic Papyrolgy. Suplement", t. 13, nr 91 F, s. 270.

47 Ibidem, s. 270.

48 R.K. Ritner, Oriental Institute Museum Notes no. 15: A Coptic Lintel from Qustul, "Journal of Near Eastern Studies", 67/2008, nr 2, s. 107-115.

49 A. Lajtar, J. van der Vliet, op. cit.,, s. 273.

50 J. Trachtenberg, Jewish Magic and Superstition. A Study in Folk-Religion, New York 1939, s. 102.

51 G. Davidson, op. cit., s. 17.

52 J. Barbel, Christos Angelos. die Anschauung von Christus als Bote und Engel in der gelehrten und volkstümlichen Literatur der christlichen Arianismus, Bonn 1941, s. 211.

53 Ibidem, 318.
} 


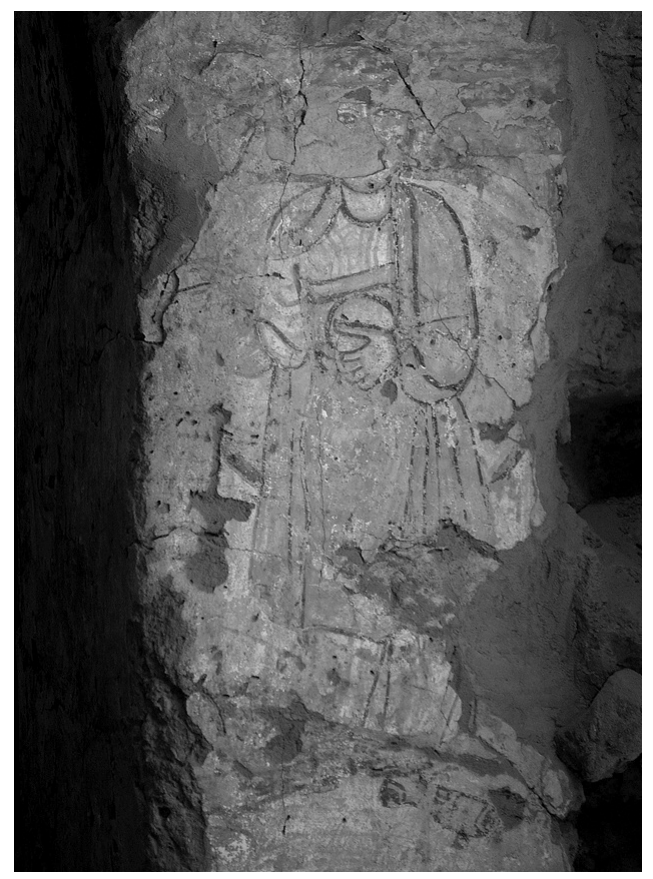

Fig. 6.

„Christus in der Engel-Siebenzahl” ${ }^{4}$. Zapewne zestawienie imion sześciu aniołów z monogramem Chrystusa na nadprożu grobu w Qustul było celowe. W ten sposób sam Zbawiciel przewodniczył tej grupie i był najwyższym archaniołem. Taka idea wyrażana była także w koptyjskich, magicznych tekstach ${ }^{55}$.

W odróżnieniu od inskrypcji, w malarstwie nubijskim nie odnotowano jak do tej pory grupowych przedstawień siedmiu archaniołów. Przedstawienia takie znane były w Egipcie, czego przykładem może być malowidło z haikalu w kościele klasztornym św. Pawła nad Morzem Czerwonym ${ }^{56}$ (Fig. 5). Ukazuje ono siedmiu archaniołów dmących w trąby, co jest niewątpliwie nawiązaniem do tekstu z Apokalipsy św. Jana. Jeśli chodzi o zestawienia dwóch archaniołów, to w Nubii najczęściej przedstawiano Michała i Gabriela lub Michała i Rafała ${ }^{57}$. Do wyjątków należy wspomniana wcześniej scena Bożego Narodzenia z Faras, w której ukazano trzech archaniołów. Z drugiej strony zachowało się wiele przedstawień indywidualnych archaniołów i aniołów. Malowidła nubijskie pierwotnie opatrzone były titulusami, jednak nie wszystkie z nich dotrwały do czasów obecnych. Stanowi to dużą trudność w interpretacji malowideł, gdyż przedstawienia poszczególnych archaniołów są do siebie podobne. Wiadomo, iż Uriel/ Ouruel przedstawiany był w sztuce nubijskiej, co odnotował już Ugo Monneret de Villard ${ }^{58}$. Odkryte niedawno przedstawienie archanioła Zedekiela w Aneksie Klasztoru na Komie H w Starej Dongoli dowodzi, iż nie tylko czterej archaniołowie, lecz także pozostali mogli być przedstawiani w malarstwie nubijskim ${ }^{59}$ (Fig. 6). Malowidło ukazujące Zedekiela niczym nie różni się od pozostałych przedstawień archaniołów i gdyby nie inskrypcja, trudno by było ustalić, że o tego archanioła chodzi. Odkrycie to jednak może wskazywać, iż archanioł ten podobnie jak dwóch pozostałych (Iael i Anael) pojawiał się w malarstwie nubijskim. Fakt, że ukazano jego pojedyncze przedstawienie może świadczyć, iż fundator tego malowidła chciał zwrócić się do Zedekiela, by prosić o łaskę lub inną formę opieki, której patronował ten szczególny archanioł.

\footnotetext{
54 J. Barbel, op. cit., 211-223.

55 C.D.G. Müller, Die Engellehre der koptischen Kirche: Untersuchungen zur Geschichte der christlichen Frömmigkeit in Ägypten, Wiesbaden 1959, s. 60.

56 P. van Moorsel et alii, Le monastère Saint-Paul près de la mere Rouge. Le Caire: 2002, 70, Figs. 43-46.

57 Por. M. Łaptaś, The Archangel Raphael..., op. cit., 461-464.

58 Ugo Monneret de Villard, La Nubia Medioevale I, Le Cairo 1935, 158, nr kat. 32.

59 M. Martens-Czarnecka, The Wall Paintings from the Monastery on Kom H in Dongola (Nubia III: Dongola III), Warszawa 2011, nr kat. 99, s. 199.
} 
Na koniec warto zwrócić uwagę na fakt, iż kilkakrotnie w dziejach Kościoła ograniczano kult siedmiu archaniołów. Kanon 35 Soboru w Laodycei (ok. 361 r.) zakazywał kultu aniołów, nazywając go idolatrią ${ }^{60}$. Mimo tych postanowień lokalnego soboru, w Bizancjum ukształtowało się święto Soboru Archanioła Michała i Wszystkich Sił Niebiańskich, obchodzone 8 września ${ }^{61}$. Wydaje się, iż kult siedmiu aniołów rozwijał się w Bizancjum silniej niż na Zachodzie. Podczas Soboru w Rzymie (745 r.), któremu przewodniczył papież Zachariasz, zezwolono na kult tylko trzech archaniołów, których imiona wymieniono w kanonicznych księgach Pisma Świętego ${ }^{62}$. Zachowane na Zachodzie zabytki, takie jak wspomniana wcześniej mozaika z kopuły narteksu kościoła św. Marka w Wenecji czy też mozaika w kopule Capella Palatina w Palermo na Sycylii, powstały pod wpływem bizantyńskim. W czaszy kopuły tej kaplicy ukazano ośmiu aniołów, z których czterech może być zidentyfikowanych jako archaniołowie Michał, Gabriel, Rafał i Uriel ${ }^{63}$. Także w Palermo, w 1516 r., w kościele San Angelo Carmelitano, Antonio Lo Duka, sycylijski kapłan, natrafił na bizantyński fresk ukazujący siedmiu archaniołów ${ }^{64}$. Przedstawieni na nim archaniołowie to: Michał, Gabriel, Barachiel, Uriel, Rafał, Jehudiel i Seatiel ${ }^{65}$. Odkrycie to doprowadziło do rozkwitu kultu siedmiu archaniołów w czasach nowożytnych na Zachodzie. Ograniczeniem kultu siedmiu archaniołów był dekret Kongregacji do spraw Świętych Obrzędów wydany w 1698 r. ${ }^{66}$

Podsumowując, na początku tego artykułu starałam się pokazać przedchrześcijańskie korzenie kultu siedmiu opiekuńczych istot na Bliskim Wschodzie. Kult ten, oparty na obserwacjach astronomicznych oraz przeświadczeniu, iż planety w powiązaniu z bogami mają istotny wpływ na życie ludzi, ewoluował w obrębie Morza Śródziemnego. Był na tyle silny, iż w Mezopotamii, Egipcie, Grecji Rzymie łączono go z opiekuńczymi istotami determinującymi życie ludzi. W chrześcijaństwie funkcję tych istot pełnili aniołowie, zaś archaniołowie byli traktowani jako elita wśród nich. Połączenie zatem siedmiu opiekuńczych bóstw z archaniołami nadało temu kultowi dodatkową rangę. Nubia z racji swego położenia była poddana długoletniej tradycji kultu siedmiu opiekuńczych bóstw. Wystarczy odnieść się do wcześniejszego kultu Hathor w Denderze. Jak już wspomniano, w świątyni tej zachował się relief ukazujący Hathor w siedmiu postaciach. Interesujące jest także to, iż przy świątyni w Denderze istniało „sanatorium”, w którym wiernych poddawano inkubacji. Na podobną funkcję Rafaelionu w Banganarti zwrócił uwagę Bogdan Żurawski, nazywając go ksenodocheionem. Kosciół w Banganarti był ważnym miejscem pielgrzymkowym, o czym świadczą wydrapane na jego ścianach inskrypcje. Wśród nich sporą grupę stanowią prośby i błagania do archanioła Rafała o wstawiennictwo i uzdrowienie. Niektóre z tych inskrypcji

60 Por. R. Cline, Ancient Angels. Conceptulizing Angeloi in the Roman Empire, Leuven 2011, s.158.

${ }_{61}$ Por. Synaxarium ecclesiae Constantinopolitanae e codice Sirmondiano (Propylaeum ad Acta sanctorum Novembris), red. H. Delehaye, Brussels 1902, szp. 203-204.

62 M. Stanzione, C. Alvino, Siedmiu archaniołów. Historia zapomnianego kultu, tłum. J. Ganobis, Kraków 2016, s. 53.

${ }^{63}$ E. Kitzinger, The Mosaics of the Cappella Palatina in Palermo: An Essay on the Choice and Arrangement of Subjects, "The Art Bulletin", 31/1949, nr 4, s. 286, Fig. 20.

${ }^{64}$ Ch. Moisan-Jablonski, Symbolika obrazu «Alegorii Bożej Opatrzności» z klasztoru Sióstr Wizytek w Krakowie, „Saeculum Christianum”, 22/2015, s. 173.

65 M. Stanzione, C. Alvino, op. cit., s. 60.

${ }^{66}$ Ibidem, s. 75. Rozkwit kultu siedmiu archaniołów wywarł wpływ na ikonografię sztuki nowożytnej, czego przykładem może być chociażby obraz przechowywany w klasztorze wizytek w Krakowie, datowany na XVIII w. ukazujący „Alegorię Bożej Opatrzności’. Ch. Moisan-Jablonski, op. cit., s. 172. 
nawiązywały bezpośrednio do księgi Tobiasza, do uzdrowienia Sary i wypędzenia demona z jej ciała. Zdaniem Żurawskiego, w Rafaelionie w Banganarti miały miejsca inkubacje ${ }^{67}$. Plan kościoła, z siedmioma apsydami po wschodniej stronie, z pewnością nie był przypadkowy. Zwłaszcza, iż w każdej z tych apsyd namalowano władcę nubijskiego pod opieką archanioła (i dwunastu apostołów na ścianach kaplic).

Zbieranie informacji o kulturze i sztuce średniowiecznej Nubii przypomina niekiedy żmudne układanie mozaiki, w której wiele tesser zaginęło. Jednak, na podstawie zachowanych inskrypcji, planu kościoła w Banganarti i faktu, iż wśród malowideł pojawiają się pojedyncze przedstawienia siedmiu archaniołów, można stwierdzić, że ich kult odgrywał w Nubii istotną rolę. Znaczenie i siła tego kultu były szczególnie silne, gdyż podbudowane długoletnią tradycją kultu siedmiu opiekuńczych bóstw na Wschodzie i w obrębie basenu Morza Śródziemnego. Interesujące jest także to, iż zestaw imion archaniołów w tekstach nubijskich był tak jednolity. Może to wskazywać na świadome rozwijanie tradycji angelologicznej w Nubii, która wykształciła się niezależnie od Egiptu i innych krajów basenu Morza Śródziemnego.

\section{Bibliografia}

\section{Teksty źródłowe}

Ancient Christian Magic. Coptic Texts of Ritual Power, red. M. Meyer, R. Smith, Princeton 1999.

Ancient Egyptian Magical Texts, red., tłum. J.F. Borghouts, Leiden 1978, „Nisaba”, t. 9. Apokryfy Starego Testamentu, oprac. i wstęp R. Rubinkiewicz, Warszawa 2000.

Augustyn św., Państwo Boże, tłum. T. Kubicki, wstęp J. Salij, t. 2, Kęty 2015.

I Księga Henocha (Etiopska), w: Apokryfy Starego Testamentu, oprac. i wstępy R. Rubinkiewicz, Warszawa 2000, s. 144-189.

III Księga Henocha (Hebrajska), tłum., wstęp., kom. M.I. Prokopowicz, https://www.academia.edu/12891881/KSI\%C4\%98GA_HENOCHA_HEBRAJSKA, 1-84 (dostęp 1.08.2019).

Marek Dion Kasjusz Kokcejan, Historia Rzymska 1, tłum. W. Madyda, Wrocław-Warszawa-Kraków 1967.

Pismo Święte Starego i Nowego Testamentu, Warszawa-Poznań 2005.

Pliniusz Gajusz Secundus, Historia Naturalna 1. Kosmologia i Geografia. Ksiegi II-VI, tłum., wstęp i kom. I. Mikołajczyk et al., Torun 2017.

Synaxarium ecclesiae Constantinopolitanae e codice Sirmondiano (Propylaeum ad Acta sanctorum Novembris), red. H. Delehaye, Brussels 1902.

\section{Opracowania}

Adams A., Kulubnarti I. The Architectural Remains, Lexington-Kentucky 1994.

Barbel J., Christos Angelos. die Anschauung von Christus als Bote und Engel in der gelehrten und volkstümlichen Literatur der christlichen Arianismus, Bonn 1941.

Buren Van Douglas E., The Seven Dots in Mesopotamian Art and their Meaning, "Archiv für Orientforschung", 13/1939/1941, s. 277-289.

${ }_{7}$ B. Żurawski, Kings and pilgrims: St. Raphael Church II at Banganarti, mid-eleventh to mid-eighteenth century, Warszawa 2014, s. 241-246. 
Büchsel M., Die Schöpfungsmosaiken von San Marco. Die Ikonographie der Erschaffung des Menschen in der frühchristlche Kunst, „Städel-Jahrbuch”, 13/1992, s. 29-80.

Chassinat É., Daumas F., Le temple de Dendera VI, Le Caire 1965.

Collon D., First Impressions. Cylinder Seals in the Ancient near East, London 2005.

Davidson G., Słownik aniołów, w tym aniołów upadtych, tłum. J. Ruszkowski, Poznań 1988.

Dawson W.R., Seven in Egyptian Texts, “Aegyptus”, 8/1927, nr 1/2, s. 97-107.

Daniélou J., Aniołowie i ich misja, tłum. K. Kubaszczyk, Warszawa 2006.

Demus O., The Mosaic Decoration of San Marco, Venice-Chicago 1988.

Dix G., The Seven Archangels and the Seven Spirits: A Study in the Origin, Development and Messianic Associations of the Two Themes, "Journal of Theological Studies", 28/1927, s. 234-235.

Dunbabin K.M.D., Mosaics of the Greek and Roman World, Cambridge-New York 1999.

Hani J., Świat symboliki chrześcijańskiej, tłum. A.Q. Lavique, Kraków 1998.

Helck W., Hathoren, sieben, w: Lexikon der Ägyptologie, t. 2, red. W. Helck, W. Westendorf, Wiesbaden 1977, kol. 1033.

Jastrzębowska E., New Testament Angels in Early Christian Art: Origin and Sources, „Światowit", 8(49)/2011, fasc. A, s. 153-164.

Kitzinger E., The Mosaics of the Cappella Palatina in Palermo: An Essay on the Choice and Arrangement of Subjects, "The Art Bulletin", 31/1949, nr 4, s. 269-292.

Kobielus S., Concordia Novi et Veteris Testamenti. Zapowiedzi dzieła odkupienia i jego spetnienie w teologii i sztuce średniowiecza, Poznań 2013.

Lechmann K., The Dome of Heaven, "The Art Bulletin", 27/1945, nr 1, s. 1-27.

Long Ch.L., The Pompeii Calendar Medallions, "American Journal of Archaeology", 96/1992, nr 3, s. 477-501.

Łajtar A., Varia Nubica XII-XIX, "Journal of Juristic Papyrology”, 39/2009, s. 31-67.

Łajtar A., Vliet van der J., Qasr Ibrim. Greek and Coptic Inscriptions, Warszawa 2010, "Journal of Juristic Papyrolgy. Suplements", t. 13.

Łaptaś M., Representation of the Angelic Hierarchy in a Nativity Scene from Faras Cathedral, "Gdańsk Archaeological Museum Reports", 2/2003, s. 137-143.

Łaptaś M., Banganarti. The Wall Paintings, "Polish Archaeology in the Mediterranean. Reports 2003", 15/2004, s. 244-252.

Łaptaś M., Archangels as Protectors and Guardians in Nubian Art, w: Between the Cataracts. Proceedings of the $11^{\text {th }}$ Conference of Nubian Studies (Warsaw 27 August-2 September 2006), t. 2.2, red. W. Godlewski, A. Łajtar, Warszawa 2010, s. 673-680.

Łaptaś M., The Archangel Raphael as protector, demon, tamer, guide and healer. Some aspects of the Archangel's activities in Nubian painting, w: Aegyptus et Nubia Christiana. The Włodzimierz Godlewski Jubilee Volume on the Occasion of his 70th Birthday, red. A. Łajtar, A. Obłuski, I. Zych, Warszawa 2016, s. 459-479.

Moisan-Jablonski Ch., Symbolika obrazu «Alegorii Bożej Opatrzności» z klasztoru Sióstr Wizytek w Krakowie, ,Saeculum Christianum”, 22/2015, s. 172-183

Nunn J.F., Ancient Egyptian Medicine, Norman OK. 2002.

Pallas D.I., Himmelsmächte, Erzengel und Engel. w: Reallexikon zur byzantinischen Kunst III, red. K. Wessel, M. Restle, Stuttgart 1978, s. 13-119.

Peers G., Subtle Bodies. Representing Angels in Byzantium, Berkeley-Los Angeles-London 2001. 
Ritner R.K., Oriental Institute Museum Notes no. 15: A Coptic Lintel from Qustul, "Journal of Near Eastern Studies", 67/2008, nr 2, s. 107-115.

Stanzione M., Carmine A., Siedmiu archaniołów. Historia zapomnianego kultu, tłum. J. Ganobis, Kraków 2016.

Stierlin H., Imperium Romanum. Od Etrusków do upadku Cesarstwa Rzymskiego, tłum. A. Stawniak, J. Kołodziejczyk, Warszawa 1997.

Trachtenberg J., Jewish Magic and Superstition. A Study in Folk Religion, New York 1939. Tyloch W., Dzieje Ksiag Starego Testamentu. Szkice z krytyki biblijnej, Warszawa 1985.

Wallraff M., Christus verus Sol: Sonnenverehrung und Christentum in der Spätantike, Münster 2001.

Weitzmann K., Late antique and early Christian book illumination, New York 1977.

Weitzmann K., Kessler H.L., The Cotton Genesis: British Library, Codex Cotton Otho B VI, Princeton 1986.

Wiggermann F.A.M., Siebengötter, w: Reallexikon der Assyriologie und vorderasiatischen Archäologie, z. 12 (5/6), red. S. Ecklin, S. Pfaffinger, Berlin-New York 2010, s. 459-466.

Yacoub M., Splendeurs des mosaïques de Tunisie, Tunis 1995.

Zerubavel E., The Seven Day Circle: The History and Meaning of the Week, New York-London 1989.

Żurawski B., Kings and pilgrims: St. Raphael Church II at Banganarti, mid-eleventh to mid-eighteenth century [=Nubia 5], Warszawa 2014. 